\title{
Effects of increased supplementation of $n-3$ fatty acids to transition dairy cows on performance and fatty acid profile in plasma, adipose tissue, and milk fat
}

\author{
M. Zachut, ${ }^{*} \dagger$ A. Arieli, $†$ H. Lehrer, ${ }^{*}$ L. Livshitz, ${ }^{\star}$ S. Yakoby, ${ }^{*}$ and U. Moallem ${ }^{\star 1}$ \\ *Department of Dairy Cattle, Institute of Animal Sciences, Volcani Center, Bet-Dagan 50250, Israel \\ †Department of Animal Science, the Robert H. Smith Faculty of Agriculture, Food and Environmental Quality Sciences, \\ the Hebrew University of Jerusalem, Rehovot 76100 , Israel
}

\begin{abstract}
The objective of this study was to determine the effects of feeding an increased amount of extruded flaxseed with high proportions of n-3 fatty acids (FA) to transition dairy cows on performance, energy balance, and FA composition in plasma, adipose tissue, and milk fat. Multiparous Israeli-Holstein dry cows $(\mathrm{n}=44)$ at $256 \mathrm{~d}$ of pregnancy were assigned to 2 treatments: (1) control cows were fed prepartum a dry-cow diet and postpartum a lactating-cow diet that consisted of 5.8\% ether extracts; and (2) extruded flaxseed (EF) cows were supplemented prepartum with $1 \mathrm{~kg}$ of extruded flaxseed ( $7.9 \%$ dry matter)/cow per d, and postpartum were fed a diet containing $9.2 \%$ of the same supplement. The EF supplement was fed until $100 \mathrm{~d}$ in milk. On average, each pre- and postpartum EF cow consumed 160.9 and $376.2 \mathrm{~g}$ of $\mathrm{C} 18: 3 \mathrm{n}-3 / \mathrm{d}$, respectively. Postpartum dry matter intake was $3.8 \%$ higher in the EF cows. Milk production was $6.4 \%$ higher and fat content was $0.4 \% \mathrm{U}$ lower in the EF group than in the controls, with no differences in fat and protein yields. Energy balance in the EF cows was more positive than in the controls; however, no differences were observed in concentrations of nonesterified fatty acids and glucose in plasma. Compared with controls, EF cows had greater proportions of C18:3n-3 in plasma and adipose tissue. The proportion of n-3 FA in milk fat was 3.7fold higher in the EF cows, and the n-6:n-3 ratio was decreased from 8.3 in controls to 2.3 in the EF cows. Within-group tests revealed that the C18:3n-3 content in milk fat in the EF cows was negatively correlated with milk fat percentage $(\mathrm{r}=-0.91)$ and yield $(\mathrm{r}=$ -0.89 ). However, no decrease in de novo synthesis of less than 16-carbon FA was found in the EF group, whereas C16:0 yields were markedly decreased. It appears that
\end{abstract}

Received June 2, 2010.

Accepted August 15, 2010.

${ }^{1}$ Corresponding author: uzim@volcani.agri.gov.il the enrichment of C18:3n-3 in milk fat was limited to approximately $2 \%$, and the potential for increasing this n-3 FA in milk is higher for cows with lower milk fat contents. In conclusion, feeding increased amounts of C18:3n-3 during the transition period enhanced dry matter intake postpartum, increased milk production, decreased milk fat content, and improved energy balance. Increased amounts of EF considerably influenced the FA profile of plasma, adipose tissue, and milk fat. However, the extent of C18:3n-3 enrichment in milk fat was limited and was negatively correlated with milk fat content and yield.

Key words: n-3 fatty acid, transition cow, milk fat

\section{INTRODUCTION}

Omega-3 (n-3) fatty acids (FA) have been shown to have several health benefits for humans; in particular, they have been shown to decrease the incidence of cardiovascular diseases, hypertension, and arthritis (Simopoulos, 2002). As a result, there is growing interest in enhancing the proportion of these FA in milk fat. Flaxseed is the most widely available botanical source of $n-3$ FA (mostly $\alpha$-linolenic acid, C18:3n-3); consequently, feeding flaxseed to dairy cows could increase the n-3 FA content and decrease the n-6:n-3 ratio in milk fat.

Various forms of flaxseed have been used to evaluate the transfer of C18:3n-3 into milk fat and results were diverse. Petit et al. (2004) fed cows with untreated whole flaxseed that provided C18:3n-3 at about $534 \mathrm{~g} /$ cow per day, and found a 1.8-fold increase in n-3 FA in milk fat, whereas Ambrose et al. (2006) observed a nearly 3 -fold increase in the C18:3n-3 content of milk for cows fed at approximately $2.0 \mathrm{~kg} / \mathrm{d}$ per cow with rolled flaxseed that contained $147 \mathrm{~g}$ of that FA, compared with the milk fat FA content of cows fed at approximately $1.85 \mathrm{~kg} / \mathrm{cow}$ per day with rolled sunflower seed. The differences between studies in the apparent transfer rates may be ascribed to differences in the proportion of C18:3n-3 in the control groups, and to the flaxseed form. 
In recent years, several studies have examined the effects of feeding dairy cows n-3 FA sources on milk production and milk fat FA composition (Gonthier et al., 2005; Akraim et al., 2007; Petit et al., 2007). These studies have shown that flaxseed was effective in increasing the n-3 FA content in plasma and milk fat, but little information exists regarding the effects of dietary n-3 FA on feed intake, blood metabolites, or energy balance in transition dairy cows. Multiparous cows supplemented with saturated fat (1.7 and $3.3 \%$ of DM pre- and postpartum, respectively) or whole flaxseed (3.3 and $11.0 \%$ of DM pre- and postpartum, respectively) beginning $6 \mathrm{wk}$ before parturition had increased liver glycogen concentrations and decreased liver concentrations of triglycerides (Petit et al., 2007). It has been suggested that feeding flaxseed to prepartum cows might be a useful strategy to increase liver concentrations of glycogen and to decrease liver concentrations of triglycerides after calving, which might prevent the development of fatty liver in the transition dairy cow (Petit et al., 2007).

The objectives of the present study were to examine the effects of feeding increased amounts of an extruded flaxseed supplement rich in C18:3n-3 to high-yielding dairy cows from 3 wk before parturition until 100 DIM on DMI, production, energy balance, plasma metabolites, and FA composition in milk fat, plasma, and adipose tissue.

\section{MATERIALS AND METHODS}

\section{Cows and Treatments}

The Volcani Center Animal Care Committee approved all of the procedures involving animals. The study was conducted from September to May to avoid heat stress. Forty-four multiparous Israeli-Holstein dry cows at the Volcani Center experimental farm (Bet Dagan, Israel), $249 \mathrm{~d}$ pregnant, were group-housed in shaded outdoor pens with adjacent outside yards, which were equipped with a real-time electronic individual feeding system. Each station was equipped with an individual identification system (S.A.E. Afikim, Kibbutz Afikim, Israel) that allowed a cow to enter a specific station and automatically recorded each meal. At $256 \mathrm{~d}$ of pregnancy (and on through 100 DIM) following $7 \mathrm{~d}$ of adaptation to the individual feeding system, cows were divided into 2 treatment groups: (1) control cows $(\mathrm{n}=$ 22) were fed prepartum a dry-cow diet, and postpartum received a lactating-cow diet according to NRC (2001) recommendations containing $5.8 \%$ ether extract (DM basis); (2) cows $(\mathrm{n}=22$ ) were fed prepartum with a dry-cow diet supplemented with extruded flaxseed (EF group; Valomega-160, Valorex, Combourtillé, France) at $1 \mathrm{~kg} /$ cow per d (7.9\% of DM), and postpartum with a lactating-cow diet containing $9.2 \%$ (DM basis) of the same supplement.

On average, EF cows were supplemented, pre- and postpartum, with $\mathrm{C} 18: 3 \mathrm{n}-3$ at 172.2 and $402.5 \mathrm{~g} / \mathrm{cow}$ per day, respectively. Compositions and contents of diets are presented in Table 1. Diets were isonitrogenous and isoenergetic, and ether extract contents also were similar in postpartum diets. The extruded supplement contained $21.7 \%$ CP, $30.4 \%$ ether extracts (DM basis), and 3.1 Mcal of $\mathrm{NE}_{\mathrm{L}} / \mathrm{kg}$ of DM. The FA profile of the postpartum diets is presented in Table 2. The Valomega supplement is a blend of $70 \%$ flaxseed and $30 \%$ wheat bran. Flaxseed mainly originated from winterseeded varieties. Flaxseed was ground through a $3-\mathrm{mm}$ screen and then mixed with wheat bran. The blend was treated with preheat and prehumidification with steam and water for 10 to $30 \mathrm{~min}$ to reach a temperature between 50 and $100^{\circ} \mathrm{C}$. After this "conditioning treatment" step, the mix was driven through a single-screw extruder with high pressure and reached an endpoint temperature below $120^{\circ} \mathrm{C}$ due to mechanical constrains. The extruded blend was then cooled and dried to reach a DM level of more than 90\% (Tradi-Lin Technology, Patent No. EP 1021960 B1).

Cows were stratified randomly within a stratum, and strata were defined by the following parameters: milk yield and fat percentage during the first 100 DIM of previous lactation, parity, BW, and BCS. In the previous lactation of the control and EF groups, average milk yields and fat contents were 43.4 and $43.4 \mathrm{~kg} / \mathrm{d}(\mathrm{SD}=$ 8.4 ), and 3.45 and $3.43 \%$ ( $\mathrm{SD}=0.42)$, respectively. The respective average parity, $\mathrm{BW}$, and BCS for the control and $\mathrm{EF}$ cows were 3.4 and $3.3(\mathrm{SD}=1.3), 734.8$ and $738.9 \mathrm{~kg}(\mathrm{SD}=75.9)$, and 3.4 and $3.3 \mathrm{U}(\mathrm{SD}=0.73)$.

\section{Measurements}

Cows were individually fed a TMR once a day at $1100 \mathrm{~h}$ in amounts that ensured 7\% refusals. Amounts of feed offered and refused were recorded daily, and individual intake was calculated throughout the entire study. Supplements were individually hand mixed into the TMR and the daily individual amounts were adjusted twice weekly.

During the dry period, cows were weighed weekly; postpartum, they were automatically weighed 3 times daily after each milking with a walking electronic scale (S.A.E. Afikim). Cows were milked at 0600, 1400, and $2100 \mathrm{~h}$, and milk production from each milking was recorded electronically (S.A.E. Afikim). Body condition score on a scale of 1 to 5 (Edmonson et al., 1989) was determined weekly from d 249 of pregnancy through the end of the study by 1 technician. Duplicate samples 
Table 1. Ingredients and chemical composition of diets during dry period and lactation

\begin{tabular}{|c|c|c|c|c|}
\hline \multirow[b]{2}{*}{ Item } & \multicolumn{2}{|c|}{ Dry cow } & \multicolumn{2}{|c|}{ Lactating cow } \\
\hline & Control & $\mathrm{EF}^{1}$ & Control & $\mathrm{EF}$ \\
\hline \multicolumn{5}{|l|}{ Ingredients, $\%$ of DM } \\
\hline Corn grain, ground & 11.7 & 11.8 & 24.5 & 24.5 \\
\hline Barley grain, rolled & 1.7 & 1.7 & 3.5 & 3.5 \\
\hline Rapeseed meal & 1.3 & 1.3 & 2.7 & 2.7 \\
\hline Soybean meal & 2.1 & 2.1 & 4.4 & 4.4 \\
\hline Sunflower meal & 2.5 & 2.5 & 7.9 & 5.3 \\
\hline Wheat bran & 1.7 & 1.7 & 3.6 & 3.6 \\
\hline Corn gluten feed & 2.1 & 2.1 & 5.7 & 4.3 \\
\hline Cottonseed & 1.5 & 1.5 & 5.6 & 3.1 \\
\hline Wheat silage & 8.7 & 8.7 & 18.2 & 18.2 \\
\hline Corn silage & 2.4 & 2.4 & 5.1 & 5.1 \\
\hline Dried distillers grain & 1.0 & 1.0 & 2.1 & 2.1 \\
\hline Oats hay & 53.6 & 53.8 & 10.7 & 10.7 \\
\hline Valomega 160 & - & 7.9 & - & 9.2 \\
\hline Calcium salts of fatty acid ${ }^{2}$ & 8.2 & - & 2.7 & - \\
\hline Urea & 0.1 & 0.1 & 0.3 & 0.3 \\
\hline Calcium bicarbonate & 0.3 & 0.3 & 0.7 & 0.7 \\
\hline Vitamins and minerals ${ }^{3}$ & 0.05 & 0.05 & 0.1 & 0.1 \\
\hline Limestone & 1.0 & 1.0 & 2.1 & 2.1 \\
\hline \multicolumn{5}{|c|}{ Chemical composition, \% of DM } \\
\hline $\mathrm{NE}_{\mathrm{L}},{ }^{4} \mathrm{Mcal} / \mathrm{kg}$ & 1.49 & 1.49 & 1.76 & 1.76 \\
\hline $\mathrm{CP}$ & 13.3 & 13.3 & 17.0 & 17.0 \\
\hline Crude $\mathrm{NDF}^{5}$ & 44.5 & 44.6 & 32.5 & 32.5 \\
\hline NDF, forage ${ }^{6}$ & 37.3 & 37.4 & 19.0 & 19.0 \\
\hline Ether extracts & 5.0 & 4.9 & 5.8 & 5.8 \\
\hline $\mathrm{Ca}$ & 0.6 & 0.6 & 0.9 & 0.9 \\
\hline $\mathrm{P}$ & 0.4 & 0.4 & 0.5 & 0.5 \\
\hline
\end{tabular}

${ }^{1}$ Extruded flaxseed (Valomega-160, Valorex, Combourtillé, France).

${ }^{2}$ Calcium salts of palm oil distillate (Adolac, Koffolk, Tel Aviv, Israel), which consisted of $15 \%$ ash and $84 \%$ fatty acids (DM basis). The fatty acid composition of the supplement was 1\% C14:0, 45.0\% C16:0, 5\% C18:0, $40 \% \mathrm{C} 18: 1$, and $9 \% \mathrm{C} 18: 2$.

${ }^{3}$ Contained (per kilogram) 16,000,000 IU of vitamin A; 3,200,000 IU of vitamin D; 48,000 IU of vitamin E; 24.0 $\mathrm{g}$ of $\mathrm{Mn} ; 24.0 \mathrm{~g}$ of $\mathrm{Zn} ; 24.0 \mathrm{~g}$ of Fe; $12.8 \mathrm{~g}$ of $\mathrm{Cu} ; 1.44 \mathrm{~g}$ of I; $0.32 \mathrm{~g}$ of Se; and $0.32 \mathrm{~g}$ of Co.

${ }^{4}$ Calculated with NRC (2001) values.

${ }^{5} \mathrm{NDF}$ from forage and nonforage ingredients.

${ }^{6} \mathrm{NDF}$ from forage ingredients.

of milk were collected from 3 consecutive milkings every 2 wk until 100 DIM for milk solids content analysis, and determination of the FA profile in milk fat. Contents of milk fat, protein, and lactose were determined according to International Dairy Federation Standard 141C (International Dairy Federation, 2000) by infrared analysis in the Israeli Cattle Breeders Association (Caesarea, Israel) laboratories.

Energy content in milk and energy balance (EB) were calculated according to NRC (2001) as follows:

$$
\begin{gathered}
\mathrm{NE}_{\mathrm{C}}=\mathrm{NE}_{\mathrm{L}} / \mathrm{kg} \text { of } \mathrm{DM} \times \mathrm{DMI} ; \\
\mathrm{NE}_{\mathrm{M}}=\mathrm{BW}^{0.75} \times 0.08 \times 1.1 ; \\
\mathrm{NE}_{\mathrm{P}}=\text { milk, } \mathrm{kg} \times[(0.0929 \times \text { fat }, \%)+(0.0547 \\
\times \text { protein, } \%)+(0.0395 \times \text { lactose }, \%)] \\
\mathrm{EB}=\mathrm{NE}_{\mathrm{C}}-\left(\mathrm{NE}_{\mathrm{M}}+\mathrm{NE}_{\mathrm{P}}\right)
\end{gathered}
$$

where $\mathrm{NE}_{\mathrm{C}}=$ net energy consumed and $\mathrm{NE}_{\mathrm{P}}=$ net energy output in milk.

Blood samples were collected 3 times weekly after morning milking, at $0800 \mathrm{~h}$ on Sunday, Tuesday, and Thursday, from commencement of dietary treatments until 21 DIM. Samples were collected from the jugular vein into vacuum tubes containing lithium heparin (Becton Dickinson Systems, Cowley, UK), and remained on ice until plasma was harvested. Plasma was collected after centrifugation at $1,500 \times g$ for $20 \mathrm{~min}$, and stored at $-31^{\circ} \mathrm{C}$ pending analysis.

Cows were examined by a veterinarian 7 to $10 \mathrm{~d}$ after calving, and clinical events were recorded.

\section{Adipose Tissue Sampling}

Adipose tissue samples from the s.c. fat pad around the pin bones were taken randomly from subgroups of cows (13 controls and $12 \mathrm{EF}$ ) for FA profile determination. Adipose samples were taken on average $10 \mathrm{~d}$ 
before cessation of supplementation, at 90 DIM. Cows were sedated by i.m. injection of $1 \mathrm{~mL}$ of Rompun $2 \%$ (xylazine base, $20 \mathrm{mg} / \mathrm{mL}$; XYL-M2 Veterinary, VMD, Arendonk, Belgium). The biopsy site, a $7 \times 7$-cm area of skin on one side of the pin bone, was prepared by clipping, washing, and sterilizing with $70 \%$ alcohol and an iodine surgical scrub. The biopsy site was anesthetized by s.c. injection of $4 \mathrm{~mL}$ of $2 \%$ lidocaine $\mathrm{HCl}$ (Esracain 2\%, $200 \mathrm{mg} / 10 \mathrm{~mL}$; Rafa Laboratories, Jerusalem, Israel). Aseptic techniques were used in making a 1.5- to 2.5-cm scalpel incision through the skin and s.c. tissues. A sample of 0.5 to $1.7 \mathrm{~g}$ of fat tissue was captured with tweezers and cut off with scissors. Immediately after the biopsy, the wound was washed again with $70 \%$ alcohol, closed with staples, and covered with an aerosol bandage. Incision sites were inspected daily for 1 wk, kept clean, and treated with aerosol bandage spray if necessary. Staples were removed after 7 to 10 d. The adipose tissue samples were thoroughly washed with saline and then frozen at $-31^{\circ} \mathrm{C}$ until FA determination.

\section{Chemical Analysis}

Total mixed rations were sampled weekly, and DM, $\mathrm{CP}, \mathrm{NDF}, \mathrm{ADF}, \mathrm{Ca}$, and $\mathrm{P}$ were determined. Feed samples were dried at $65^{\circ} \mathrm{C}$ for $24 \mathrm{~h}$ and then ground to pass through a 1.0-mm screen (Retsch SM 100, Retsch GmbH, Haan, Germany). Samples were analyzed for N (AOAC, 1990; method 984.13), Ca (AOAC, 1990; method 935.13), and P (AOAC, 1990; method 964.06); $\mathrm{NDF}$ and ADF contents were determined with Ankom (Ankom Technology, Fairport, NY) equipment (NDF by using $\alpha$-amylase and sodium sulfite). Additional diet sample portions were dried at $100^{\circ} \mathrm{C}$ for $3 \mathrm{~h}$, and calculations for nutrient contents were conducted accordingly. Values of $\mathrm{NE}_{\mathrm{L}}$ were calculated according to NRC values (NRC, 2001).

Plasma glucose was determined with a glucose reagent kit (Glucose UV, $10 \times 50 \mathrm{~mL}$; Raichem, San Diego, $\mathrm{CA}$ ) that used 2 enzymatic reactions with hexokinase and glucose-6-phosphate dehydrogenase to generate a UV emission that was correlated with the sample glucose concentration. The samples were examined at $340 \mathrm{~nm}$ with an optical density reader (Sunrise, Tecan, Salzburg, Austria), and results were calibrated against known glucose concentrations. Similarly, plasma NEFA concentrations were determined with a Wako NEFA C Test Kit (Wako Chemicals GmbH, Neuss, Germany), in which 3 enzymatic reactions with acyl-coA-synthetase, acyl-coA-oxidase, and peroxidase generated a UV emission that was examined at $550 \mathrm{~nm}$ with an optical density reader and calibrated against known NEFA concentrations.
Table 2. Fatty acid (FA) composition (g/100 g of FA) of postpartum diets

\begin{tabular}{|c|c|c|c|c|}
\hline \multirow[b]{2}{*}{ Fatty acid ${ }^{1}$} & \multicolumn{2}{|c|}{ Diet } & \multirow[b]{2}{*}{ SEM } & \multirow[b]{2}{*}{$P<$} \\
\hline & Control & $\mathrm{EF}^{2}$ & & \\
\hline $8: 0-15: 0$ & 0.99 & 0.31 & 0.03 & 0.003 \\
\hline $16: 0$ & 36.98 & 11.94 & 0.44 & 0.001 \\
\hline $16: 1$ & 0.30 & 0.21 & 0.01 & 0.09 \\
\hline $17: 0$ & 0.11 & 0.13 & 0.06 & 0.86 \\
\hline $17: 1$ & 0.05 & 0.07 & 0.005 & 0.11 \\
\hline $18: 0$ & 4.27 & 3.73 & 0.26 & 0.29 \\
\hline $18: 1 n-9$ & 24.68 & 22.47 & 0.92 & 0.23 \\
\hline $18: 2 n-6$ & 25.53 & 26.86 & 1.93 & 0.68 \\
\hline Trans-18:3 & 0.00 & 0.11 & 0.07 & 0.42 \\
\hline $18: 3 n-6$ & 0.04 & 0.24 & 0.01 & 0.006 \\
\hline $18: 3 n-3$ & 1.51 & 27.85 & 1.56 & 0.007 \\
\hline $18: 4 n-3$ & 0.72 & 0.20 & 0.04 & 0.02 \\
\hline $19: 1$ & 0.02 & 0.12 & 0.08 & 0.50 \\
\hline $20: 0$ & 0.58 & 0.44 & 0.01 & 0.02 \\
\hline 20:1n-9 & 0.60 & 0.38 & 0.03 & 0.04 \\
\hline $20: 2 \mathrm{n}-6$ & 0.10 & 0.13 & 0.02 & 0.36 \\
\hline $20: 3 n-6$ & 0.19 & 0.19 & 0.02 & 1.00 \\
\hline $20: 3 n-3$ & 0.54 & 0.32 & 0.15 & 0.41 \\
\hline $20: 4 n-6$ & 0.05 & 0.19 & 0.03 & 0.07 \\
\hline $20: 4 n-3$ & 0.07 & 0.14 & 0.008 & 0.03 \\
\hline $20: 5 n-3$ & 0.05 & 0.07 & 0.06 & 0.87 \\
\hline $22: 3 n-6$ & 0.52 & 0.39 & 0.02 & 0.07 \\
\hline $22: 3 n-3$ & 0.13 & 0.24 & 0.02 & 0.06 \\
\hline $22: 4 n-6$ & 0.03 & 0.34 & 0.04 & 0.03 \\
\hline $22: 5 n-6$ & 0.27 & 0.56 & 0.06 & 0.07 \\
\hline $22: 4 n-3$ & 0.02 & 0.17 & 0.03 & 0.06 \\
\hline $22: 5 n-3$ & 0.00 & 0.09 & 0.02 & 0.09 \\
\hline $22: 6 n-3$ & 0.04 & 0.18 & 0.02 & 0.04 \\
\hline $23: 0$ & 0.25 & 0.28 & 0.03 & 0.49 \\
\hline $24: 0$ & 0.12 & 0.16 & 0.007 & 0.09 \\
\hline $24: 1$ & 0.03 & 0.27 & 0.02 & 0.02 \\
\hline SFA & 43.59 & 17.20 & 0.39 & 0.001 \\
\hline MUFA & 26.22 & 24.16 & 0.93 & 0.26 \\
\hline PUFA & 30.20 & 58.65 & 0.57 & 0.001 \\
\hline $\mathrm{n}-3$ & 3.06 & 29.24 & 1.43 & 0.006 \\
\hline n-6 & 26.75 & 28.97 & 1.83 & 0.48 \\
\hline$n-6 / n-3$ & 8.81 & 1.00 & 0.52 & 0.009 \\
\hline
\end{tabular}

${ }^{1} \mathrm{SFA}=$ sum of saturated FA; MUFA $=$ sum of monounsaturated FA PUFA $=$ sum of polyunsaturated FA; $\mathrm{n}-3=$ sum of $\mathrm{n}-3 \mathrm{FA}$; and $\mathrm{n}-6$ $=$ sum of n- 6 FA.

${ }^{2}$ Extruded flaxseed.

\section{Fatty Acid Profiles of Plasma, Milk Fat, and Adipose Tissue}

Fatty acids in plasma $(100 \mu \mathrm{L})$ and adipose tissue samples $(100 \mathrm{mg})$ were extracted according to Moallem et al. (1999). Briefly, the samples were saponified in a mixture of $60 \% \mathrm{KOH}$ and ethanol, extracted with petroleum ether, and methylated with $5 \%$ sulfuric acid in methanol. Plasma FA was analyzed with a model 5890 series 2 gas chromatograph (Hewlett-Packard, Palo Alto, CA) equipped with a capillary column $(30 \mathrm{~m}$ $\times 0.53 \mathrm{~mm}, 0.5 \mathrm{~mm}$; Agilent Technologies, Santa Clara, $\mathrm{CA}$ ) and a flame-ionization detector. The column was maintained at $160^{\circ} \mathrm{C}$ isothermal. Nitrogen was the carrier gas with a linear velocity of $22 \mathrm{~cm} / \mathrm{s}$; injection vol- 
ume was $2 \mu \mathrm{L}$. Adipose FA was analyzed with a model 7890N gas chromatograph (Agilent Technologies, Santa Clara, CA) equipped with a DB-23 capillary column $(60 \mathrm{~m} \times 0.25 \mathrm{~mm}, 0.25 \mu \mathrm{m}$; Agilent Technologies $)$ and a flame-ionization detector. The initial temperature of the column was $130^{\circ} \mathrm{C}$, which was increased at $6.5^{\circ} \mathrm{C} /$ min to $170^{\circ} \mathrm{C}$, then at $2.75^{\circ} \mathrm{C} / \mathrm{min}$ to $215^{\circ} \mathrm{C}$, where it was held for $18 \mathrm{~min}$ before being increased at $40^{\circ} \mathrm{C} / \mathrm{min}$ to $230^{\circ} \mathrm{C}$ for the remainder of the analysis. Hydrogen was used as the carrier gas with a linear velocity of 1.6 $\mathrm{m} / \mathrm{min}$; injection volume was $1 \mu \mathrm{L}$ with a split ratio of $1: 100$.

Milk samples from 3 milkings at each session were composited based on the milk production at each milking. Milk samples from 6 control and $7 \mathrm{EF}$ cows, all randomly selected, were analyzed for milk fat FA profile every $30 \mathrm{~d}$ (a total of 18 control and $21 \mathrm{EF}$ analyses). Milk fat FA profiles were examined after extraction by AOAC method 996.06 (AOAC, 1990), and GC was performed at Milouda Laboratories (Haifa, Israel) with an Agilent model $6890 \mathrm{~N}$ gas chromatograph (Agilent Technologies) equipped with a Quadrex capillary column $(60 \mathrm{~m} \times 0.25 \mathrm{~mm}, 0.25 \mu \mathrm{m}$; Quadrex, Woodbridge, CT) and an FID. The initial column temperature was $60^{\circ} \mathrm{C}$. The temperature was increased at $5^{\circ} \mathrm{C} / \mathrm{min}$ to $225^{\circ} \mathrm{C}$, where it was maintained. Carrier gas was hydrogen with a linear velocity of $1.6 \mathrm{~m} / \mathrm{min}$; injection volume was $1 \mu \mathrm{L}$, with a split ratio 1:100. The individual fat yields of each cow at each sampling day were used for calculation of the specific FA yields. The specific FA yields were calculated as described by Glasser et al. (2007).

\section{Statistical Analysis}

Continuous variables (milk, DMI, energy balance, and blood metabolites) were analyzed as repeated measurements with the MIXED procedure of SAS (SAS Institute, 2002). The effects of the treatment $\times$ DIM and treatment $\times$ parity $\times$ DIM interactions were tested and found to be not significant for each dependent variable; therefore, these effects were excluded from the model. Dry matter intake was analyzed separately for pre- and postpartum periods. Each production variable was analyzed, with the specific data of the 100 DIM of the previous lactation used as a covariable.

The final model used was as follows:

$$
\begin{aligned}
\mathrm{Y}_{i j k l m}= & \mu+\mathrm{T}_{i}+\mathrm{L}_{j}+\mathrm{C}(\mathrm{T} \times \mathrm{L})_{i j k}+\mathrm{DIM}_{i j k l} \\
& +\mathrm{DIM}_{i j k l} \times \mathrm{DIM}_{i j k l}+\mathrm{E}_{i j k l m},
\end{aligned}
$$

where $\mathrm{Y}_{i j k l m}=$ dependent variable, $\mu=$ overall mean, $\mathrm{T}_{i}$ $=$ treatment effect $i, \mathrm{~L}_{j}=$ parity, $j=2$ or $>2, \mathrm{C}(\mathrm{T} \times$
$\mathrm{L})_{i j k}=$ cow $k$ nested in treatment $i$ and cow nested in parity $_{j}, \mathrm{DIM}_{i j k l}=$ days in milk as continuous variable and $\mathrm{E}_{i j k l m}=$ random residual.

The autoregressive order 1 was used as a covariance structure in the model. Whenever the quadratic effect was found to be not significant, it was excluded from the model and the model was rerun.

Compositions of FA in plasma and milk fat were also analyzed as repeated measurements using the MIXED procedure of SAS (SAS Institute, 2002). The model included the effects of DIM and of the interaction treatment $\times$ DIM. Because the interaction treatment $\times$ DIM was not significant for any FA that was tested, it was excluded from the model.

Body weight and FA composition in adipose tissue were analyzed with the General Linear Models procedure of SAS, and the PROC REG procedure of SAS (SAS Institute, 2002) was used for correlation analysis.

Least squares means and adjusted SEM are presented in Tables 2 to $7 ; P<0.05$ was accepted as significant unless otherwise stated.

\section{RESULTS AND DISCUSSION}

\section{DMI and Milk Production}

Fatty acid profiles of diets are presented in Table 2. The C16:0 FA content was 3.0 times higher in the control than in the EF diet. The C18:3n-3 was 18 times higher $(P<0.007)$ and the total n-3 FA contents were 9.6 times higher $(P<0.006)$ in the EF diet than in the control. Total saturated fatty acids (SFA) content in the $\mathrm{EF}$ diet was $40 \%$ of that in the control diet $(P<$ 0.001) and total polyunsaturated fatty acids (PUFA) content was almost twice as high in the EF as it was in the control diet $(P<0.001)$.

Average prepartum DMI was not affected by treatment, whereas the postpartum DMI and energy intake were $3.8(P<0.006)$ and $5 \%(P<0.001)$, respectively, higher in EF versus control cows (Table 3). The increased intake of the EF cows is consistent with the results of Petit et al. (2007), who found that a diet containing a high proportion of SFA caused lower feed intake than one rich in unsaturated FA. However, several other studies have found that decreased intake resulted from abomasal infusion of unsaturated FA (Drackley et al., 1992; Bremmer et al., 1998) or from feeding cows increasing amounts of unsaturated FA at the expense of SFA (Harvatine and Allen, 2006). In addition, in a study conducted in our laboratory, feeding transition cows with the calcium salts of long-chain fatty acids rich in PUFA decreased DMI pre- and postpartum compared with prilled fat rich in SFA (Moallem et al., 
Table 3. Mean treatment effects on pre- and postpartum DMI, milk yield and composition, and BW changes

\begin{tabular}{lcccl}
\hline & \multicolumn{2}{c}{ Treatment $^{1}$} & & \\
\cline { 2 - 2 } Item & Control & EF & SEM & $P<$ \\
\hline Intake & & & & \\
Prepartum DMI, kg/d & 11.3 & 11.7 & 0.2 & 0.14 \\
Postpartum DMI, kg/d & 26.1 & 27.1 & 0.2 & 0.006 \\
Postpartum NE intake, Mcal/d & 46.1 & 48.4 & 0.4 & 0.001 \\
Milk and milk components production & & & & \\
Milk, kg/d & 49.5 & 52.9 & 0.5 & 0.001 \\
FCM 3.5\%, kg/d & 46.8 & 46.6 & 0.6 & 0.8 \\
Fat, \% & 3.63 & 3.23 & 0.06 & 0.001 \\
Protein, \% & 2.94 & 2.97 & 0.03 & 0.60 \\
Lactose, \% & 4.98 & 4.98 & 0.03 & 0.93 \\
Fat, kg/d & 1.87 & 1.77 & 0.5 & 0.13 \\
Protein, kg/d & 1.51 & 1.60 & 0.03 & 0.08 \\
Lactose, kg/d & 2.57 & 2.70 & 0.06 & 0.15 \\
Urea, g/100 mL & 0.04 & 0.04 & 0.00 & 0.15 \\
Energy in milk, Mcal/d & 34.3 & 33.6 & 0.4 & 0.58 \\
BW and energy balance & & & & \\
BW at 256 d of pregnancy, kg & 734.8 & 738.9 & 13.3 & 0.76 \\
BW 3 d postcalving, kg & 672.3 & 686.6 & 6.3 & 0.11 \\
BW at 100 DIM, kg & 617.5 & 649.7 & 8.8 & 0.001 \\
Energy balance, Mcal/d & 0.8 & 2.3 & 0.35 & 0.003 \\
\hline
\end{tabular}

${ }^{1}$ Treatments were as follows: control, dry cows at $256 \mathrm{~d}$ of pregnancy fed a dry-cow diet and postpartum lactating-cow diet consisting of $5.8 \%$ ether extracts; EF, supplemented prepartum at $1 \mathrm{~kg} / \mathrm{d}$ per cow $(7.9 \%$ of DM) with extruded flaxseed, and postpartum until 100 DIM with a diet containing $9.2 \%$ of the same supplement.

2007). Gonthier et al. (2005) found that feeding cows with extruded flaxseed at $12.7 \%$ of DM did not affect DMI, whereas Chilliard et al. (2009) reported that feeding cows with a supplement containing $70 \%$ extruded flaxseed $(21.2 \%$ of DM) decreased DMI. The inconsistency between DMI results obtained in different studies might be due to differences in the amounts and forms of supplements, but also could be due to differences in their palatability, rather than to the FA composition of supplements per se.

Milk yield until 100 DIM was $6.4 \%$ higher $(P<$ $0.004)$ and fat content was $0.4 \mathrm{U}(11 \%)$ lower in the EF cows than in the controls $(P<0.001)$, whereas fat yield, FCM, and milk energy output were not affected by treatment (Table 3 ). These results are in line with findings from Petit et al. (2007), in which cows fed whole flaxseed at 3.3 and $11 \%$ of DM prepartum and postpartum, respectively, produced more milk with a lower milk fat percentage than did those fed a supplement rich in SFA. Decreased milk fat percentage was also observed by Mustafa et al. (2003) in cows fed $7 \%$ raw flaxseed, and by Chilliard et al. (2009) in cows fed a supplement containing $70 \%$ extruded flaxseed at $21.2 \%$ of the diet. However, Gonthier et al. (2005) did not observe an effect on DMI from feeding extruded flaxseed (12.7\% of DM), whereas Chilliard et al. (2009) found that cows fed a supplement with $70 \%$ extruded flaxseed (21.2\% of DM) had decreased DMI. Discrepancies between studies might be related to differences among the amounts and forms of supplemental flaxseed, or to interactions with other diet components, as suggested by Chilliard et al. (2009).

\section{BW, BCS, EB, and Plasma Metabolite Concentrations}

Prepartum average BW were similar in the 2 groups, but postpartum, the control cows lost more BW than did the EF cows; at 100 DIM, the EF cows were, on average, $32.2 \mathrm{~kg}$ heavier than the controls (Table 3 , Figure 1A; $P<0.001)$. Similarly, the control cows continued to lose BCS until wk 8 postpartum, whereas the EF cows started to gain BCS from wk 6 postpartum on average. Prepartum, BCS of control and EF cows was 3.57 and $3.49(\mathrm{SEM}=0.08 ; P>0.1)$, respectively, and at $100 \mathrm{DIM}$ it was 2.24 and $2.36(\mathrm{SEM}=0.04 ; P<$ $0.06)$, respectively.

Calculated EB during 100 DIM was 1.5 Mcal higher in the $\mathrm{EF}$ versus the control cows $(2.3$ and $0.8 \mathrm{Mcal} / \mathrm{d}$, respectively; $P<0.004$; Table 3 and Figure 1B). The $\mathrm{EB}$ nadir was lower in the control cows than in the EF cows $(-7.7$ and -3.6 Mcal, respectively; $P<0.004)$; however, days to negative EB nadir and time to return to positive EB were not affected by treatment. Nevertheless, differences in EB were not reflected in plasma concentrations of glucose $(P<0.4)$ or NEFA $(P$ $<0.9)$ in control and EF cows $(70.9$ and $68.9 \mathrm{mg} / \mathrm{dL}$, respectively, $\mathrm{SEM}=1.5$; and 287.1 and $298.6 \mu \mathrm{Eq} / \mathrm{L}$, respectively, SEM $=32$ ). Moreover, records of clinical 
events revealed no differences between groups in frequency of clinical disorders (data not shown).

Energy consumption was 5\% higher and energy output in milk was 2\% lower in EF versus control cows, which contributed to improved EB. Similar results were reported when transition cows were fed a postpartum diet containing $11.0 \%$ whole flaxseed; these cows had a higher EB than did those fed an SFA-rich fat supplement (Petit et al., 2007). Several studies examined the effectiveness of milk fat depression (MFD) diets during early lactation (Bernal-Santos et al., 2003; CastañedaGutiérrez et al., 2005) as an approach to decrease energy expenditure, but they failed to reduce fat synthesis immediately after calving and, consequently, did not improve cows' EB status. In a recent study, Odens et al. (2007) used larger amounts of conjugated linoleic acid, and found that fat yield was depressed within days after parturition and, indeed, the EB of these cows was improved. In the present study, the EF cows channeled energy toward milk production at the expense of fat production, so that the total energy output in milk did not reduce. However, the high energy intake of the EF cows contributed to EB by improving the other side of the EB equation (energy consumption).

\section{Plasma and Adipose Tissue Fatty Acids Composition}

The content of C16:0 in plasma was higher in the control than in the EF cows $(P<0.004$; Table 4$)$, whereas that of C18:3n-3 was greater in the latter: 1.03 and 5.43 $\mathrm{g}$ per $100 \mathrm{~g}$ in control and EF cows, respectively $(P<$ 0.001). No differences were observed between groups in the proportions of total SFA, monounsaturated fatty acids (MUFA) and PUFA in plasma. However, the plasma n-6/n-3 ratio was considerably lower in the EF than in the control cows: 8.2 and 48.9 , respectively $(P$ $<0.001)$.

The adipose tissue FA profile is presented in Table 5 . No differences were observed between groups in composition of the prominent FA in adipose tissue, i.e., C16:0, C18:0, and C18:1n-9, which accounted for $\sim 80 \%$ of the total FA. The C14:0 $(P<0.02), \mathrm{C} 18: 2 \mathrm{n}-6(P<$ $0.03)$ and $C 18: 3 \mathrm{n}-3(P<0.004)$ contents were higher in the EF group than in the controls, whereas C20:4n-6 was higher in the control $(P<0.03)$. No differences between groups were observed in total SFA and MUFA, but total PUFA tended to be higher in the EF than in the control animals $(P<0.08)$. In the present study, the $n-6 / n-3$ ratio in adipose tissue was lower in the EF cows than in the controls: 0.32 and $1.01 \mathrm{~g}$ per 100 g, respectively $(P<0.01)$, whereas when Bilby et al. (2006) compared cows that were fed calcium salt of fish oil-enriched lipid with those fed oil of whole cottonseed (at $1.9 \%$ of dietary DM), they found no difference in n- $6 / n-3$ ratio. It could be presumed that the greater amount of n-3 FA supplementation in the present study than in that of Bilby et al. (2006) was more effective in altering the FA composition in adipose tissue.

The temporal FA profile in plasma revealed that relative FA composition was changed over time during the transition period. In general, the plasma FA profile was similar to that found by Petit et al. (2007). In both groups, there was a trend to increased relative concentrations of C16:0 (Figure 2A), C18:0, and C18:1n-9 (Figure 2B) in plasma as calving approached, followed by declines that started a few days post calving. Also, the major FA in adipose tissue, as determined in the present study, were C16:0 $(\sim 30 \%), \mathrm{C} 18: 0(\sim 17 \%)$ and C18:1n-9 (approximately 41\%; Table 5), similar to those reported elsewhere (Rukkwamsuk et al., 2000; Bilby et al., 2006). The increased relative content of these components in plasma FA reflected the contribution of FA derived from peripartum mobilization of adipose tissue, as also reported by Rukkwamsuk et al. (2000) and Petit et al. (2007). In contrast, relative content of C20:3n-6 (Figure 2C) and C20:4n-6 (Figure 2D) in plasma FA in both groups started to decline a few weeks before calving, and that of C20:3n-6 continued after calving. Indeed, the proportions of these FA in plasma were significantly affected by DIM (Table 4). The C18:2n- 6 and C18:3n-3 can be converted in the liver to longer chain PUFA, such as C20:3n- 6 and C20:4n-6, by desaturation and elongation enzyme systems (Wathes et al., 2007); therefore, the decline in C20:3n-6 and C20:4n-6 proportions in plasma FA might be partly attributed to the decrease in DMI as calving approached and consequently the decline in availability of precursors for elongated FA. Moreover, it is plausible that the intensive changes in liver metabolism around calving might include decreased desaturation and elongation activity, with subsequent declines in the proportions of these FA in plasma.

\section{Milk Fatty Acid Composition and Yields}

In the present study, to avoid effects of early lactation on milk-fat composition, the FA content in milk fat was analyzed and presented only in samples taken at or after 25 DIM. Profile and yields of FA in milk fat are presented in Tables 6 and 7, respectively. The proportion and yield of C16:0 in milk fat were 1.5 times higher in control than in EF cows $(P<0.001)$. The proportions of $\mathrm{C} 18: 3 \mathrm{n}-3$ and $\mathrm{C} 22: 5 \mathrm{n}-3$ in milk fat were $5.1(P<0.001)$ and $3(P<0.008)$ times as great in $\mathrm{EF}$ as in control cows, whereas the daily yield of C18:3n-3 was 4.6 times as high in the $\mathrm{EF}$ as in the control cows: 24.1 and $5.2 \mathrm{~g} / \mathrm{d}$, respectively $(P<0.001)$. The overall n-3 FA content in milk fat was 3.7 times higher in the 

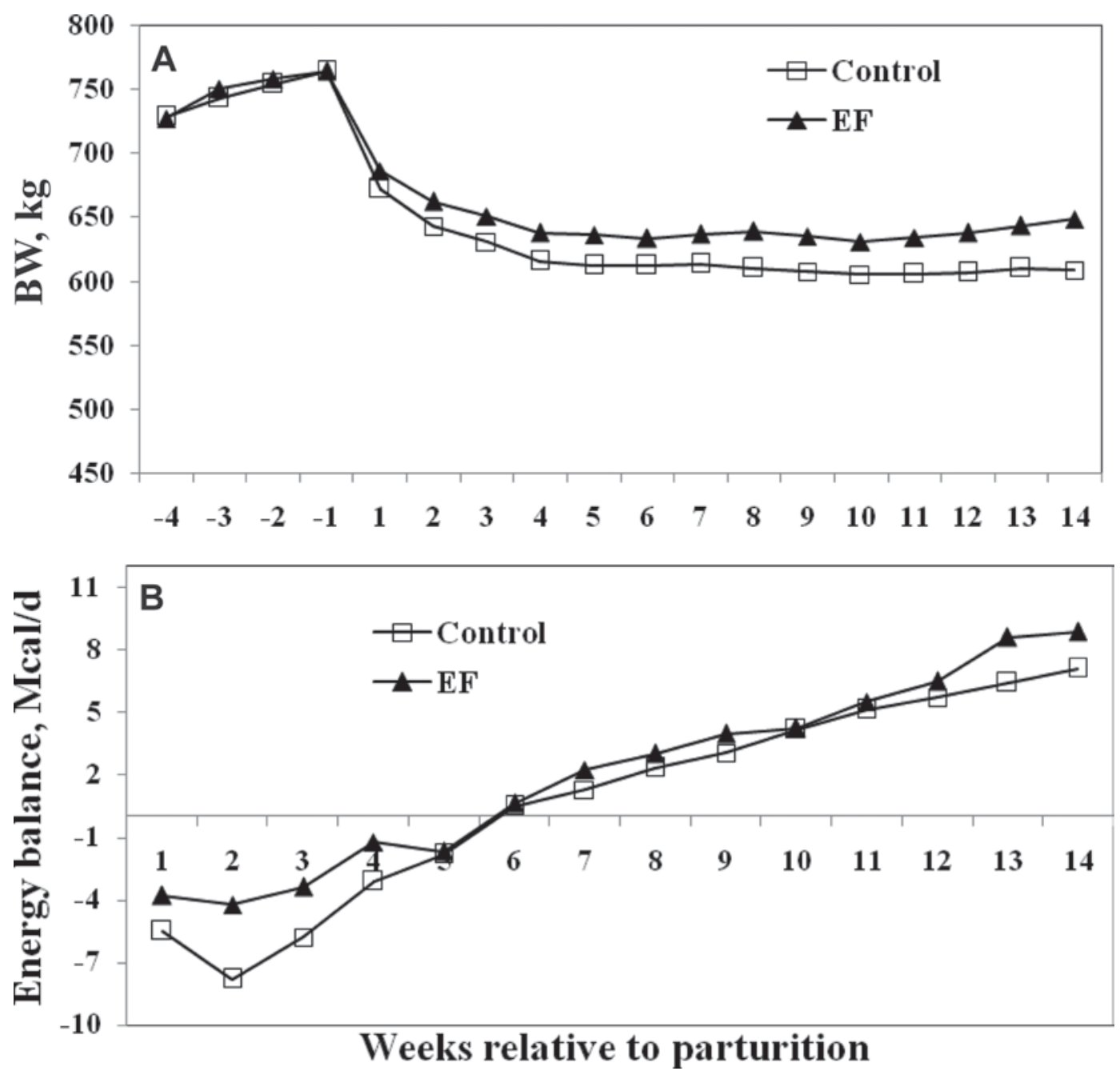

Figure 1. Temporal changes in (A) BW and (B) energy balance (EB) in control ( $\square$ ) dry cows from 256 d of pregnancy fed a dry-cow diet and a lactating-cow diet postpartum containing $5.8 \%$ ether extracts, and extruded flaxseed $(\mathrm{EF}, \mathbf{\Lambda})$ cows supplemented prepartum with extruded flaxseed at $1 \mathrm{~kg} /$ cow per day $(7.9 \%$ of DM) and postpartum through 100 DIM with a lactating cow diet containing $9.2 \%$ of the same supplement. The SEM were $3.0 \mathrm{~kg}$ and $0.35 \mathrm{Mcal} / \mathrm{d}$ for BW and EB, respectively.

EF than in the control group $(P<0.001)$, and the n- $6 / \mathrm{n}-3$ ratio was reduced from 8.3 in the control to 2.3 in the EF group $(P<0.001)$. The proportion of SFA in milk fat was $10.9 \%$ higher in the control than in the EF group $(P<0.001)$, whereas those of MUFA and PUFA in milk fat were higher in the EF cows than in controls $(P<0.002)$.

Transfer rates of $\mathrm{C} 18: 3 \mathrm{n}-3$ from diet to milk fat averaged 22.7 and $5.9 \%$ in the control and EF cows, respectively $(P<0.001)$, which matches the results of Chilliard et al. (2009), who found that control cows had greater transfer efficiency than those supplemented with extruded linseed. Moreover, in the present study, the transfer rate of C18:3n-3 in the EF cows was negatively correlated with dietary 18:3n-3 intake $(\mathrm{r}=-0.52 ; P<$ 0.02 ), which implies that the transfer rate decreased as supplemental C18:3n-3 increased. The transfer rate of $\mathrm{C} 18: 3 \mathrm{n}-3$ in $\mathrm{EF}$ cows in the present study was higher than that reported by Gonthier et al. (2005) for raw, micronized, and extruded flaxseed feed $(12.7 \%$ of DM) or by Chilliard et al. (2009), who fed cows a diet containing $21.2 \%$ of a supplement containing $70 \%$ extruded flaxseed. Discrepancies between studies could be attributed to differences in the supplement forms, intakes, and production level, but also to the high contents of extruded flaxseed in diets used by Gonthier et al. (2005) and Chilliard et al. (2009), which might influence transfer rates.

\section{Enrichment of n-3 FA in Milk Fat and Interaction with Milk Fat Content}

A high and positive correlation was demonstrated between dietary C18:3n-3 intake and its content $(r=0.90$; 
Table 4. Mean treatment effects on plasma fatty acid (FA) composition (g/100 g of FA)

\begin{tabular}{|c|c|c|c|c|c|}
\hline \multirow[b]{2}{*}{ Item $^{1}$} & \multicolumn{2}{|c|}{ Treatment $^{2}$} & \multirow[b]{2}{*}{ SEM } & \multicolumn{2}{|c|}{ Effect, $P<$} \\
\hline & Control & $\mathrm{EF}$ & & Treatment & DIM \\
\hline $14: 0$ & 0.83 & 0.89 & 0.07 & 0.60 & 0.10 \\
\hline $16: 0$ & 20.9 & 17.2 & 0.64 & 0.004 & 0.97 \\
\hline $16: 1$ & 2.54 & 1.96 & 0.20 & 0.07 & 0.76 \\
\hline $18: 0$ & 18.8 & 18.3 & 1.6 & 0.84 & 0.07 \\
\hline $18: 1$ & 14.8 & 16.0 & 0.5 & 0.15 & 0.23 \\
\hline $18: 2 n-6$ & 35.9 & 35.3 & 1.5 & 0.89 & 0.07 \\
\hline Cis C18:2n-6 & 1.50 & 1.51 & 0.16 & 0.98 & 0.06 \\
\hline $18: 3 n-3$ & 1.03 & 5.43 & 0.30 & 0.001 & 0.64 \\
\hline $20: 3 n-6$ & 1.47 & 0.88 & 0.17 & 0.04 & 0.03 \\
\hline $20: 4 n-6$ & 2.76 & 2.66 & 0.22 & 0.77 & 0.04 \\
\hline SFA & 40.2 & 36.2 & 2.0 & 0.18 & 0.18 \\
\hline MUFA & 17.4 & 18.0 & 0.45 & 0.38 & 0.13 \\
\hline PUFA & 42.5 & 45.9 & 2.15 & 0.29 & 0.39 \\
\hline $\mathrm{n}-3$ & 1.03 & 5.43 & 0.30 & 0.001 & 0.64 \\
\hline $\mathrm{n}-6$ & 41.4 & 40.4 & 1.8 & 0.72 & 0.36 \\
\hline$n-6 / n-3$ & 48.9 & 8.2 & 4.9 & 0.001 & 0.53 \\
\hline
\end{tabular}

${ }^{1} \mathrm{SFA}=$ sum of saturated FA; MUFA $=$ sum of monounsaturated FA; PUFA $=$ sum of polyunsaturated FA; $\mathrm{n}-3$ $=$ sum of $\mathrm{n}-3 \mathrm{FA}$; and $\mathrm{n}-6=$ sum of $\mathrm{n}-6 \mathrm{FA}$.

${ }^{2}$ Treatments were as follows: control $=$ dry cows at $256 \mathrm{~d}$ of pregnancy fed a dry-cow diet and postpartum lactating cow diet consisting of $5.8 \%$ ether extracts; $\mathrm{EF}=$ supplemented prepartum at $1 \mathrm{~kg} / \mathrm{d}$ per cow $(7.9 \%$ of DM) with extruded flaxseed, and postpartum until 100 DIM with a diet containing $9.2 \%$ of the same supplement.

$P<0.001)$ and yield $(\mathrm{r}=0.96 ; P<0.001)$ in milk fat. However, within-group tests of $\mathrm{EF}$ cows showed that correlations between dietary C18:3n-3 intake and its content and yields in milk fat were low and not significant $(P<0.40$ and $P<0.12$, respectively). In addition, the content of $\mathrm{C} 18: 3 \mathrm{n}-3$ in milk fat reached a maximum of $\sim 2 \%$, which implies that the enrichment of this FA in milk fat by feeding partly protected flaxseed is limited, and that increasing the dietary supply of C18:3n-3 does not help to enrich milk fat. The average content of C18:3n-3 in milk fat in EF cows was $1.47 \mathrm{~g} / 100 \mathrm{~g}$ of FA, which is higher than that reported in several studies fed a variety of sources and amounts of flaxseed (Gonthier et al., 2005; Petit et al., 2007; Chilliard et al., 2009). In a recent study, Khas-Erdene et al. (2010) found that duodenal infusion of $120 \mathrm{~g} / \mathrm{d}$ of $\mathrm{C} 18: 3$ (as free fatty acids) increased the $\mathrm{C} 18: 3 \mathrm{n}-3$ content in milk fat to $25.4 \%$, but did not report yields. However, EF cows in the present study produced on average $24.1 \mathrm{~g} / \mathrm{d}$ of C18:3n-3, which is, to the best of our knowledge, the highest amount achieved in cows fed flaxseed. The high amounts could be related to the high milk and fat yields in the present study, but also might be attributed to the increased amounts of C18:3n-3 consumed by the cows: average of $376.2 \mathrm{~g} / \mathrm{d}$ per cow.

Interestingly, within-group tests also revealed that the C18:3n-3 content in milk fat FA in the EF group was highly and negatively correlated with milk fat percentage $(\mathrm{r}=-0.92 ; P<0.0001 ;$ Figure $3 \mathrm{~A})$ and yield $(\mathrm{r}$ $=-0.89 ; P<0.0001 ;$ Figure $3 \mathrm{~B})$, whereas this pattern was not found in the controls $(\mathrm{r}=-0.14 ; P<0.55)$.
Table 5. Mean treatment effects on fatty acid (FA) composition $(\mathrm{g} / 100 \mathrm{~g}$ of $\mathrm{FA})$ in adipose tissue

\begin{tabular}{|c|c|c|c|c|}
\hline \multirow[b]{2}{*}{ Item $^{1}$} & \multicolumn{2}{|c|}{ Treatment $^{2}$} & \multirow[b]{2}{*}{ SEM } & \multirow[b]{2}{*}{$P<$} \\
\hline & Control & $\mathrm{EF}$ & & \\
\hline 14:0 & 2.67 & 3.39 & 0.19 & 0.02 \\
\hline 16:0 & 30.8 & 30.2 & 1.48 & 0.77 \\
\hline $16: 1$ & 2.93 & 4.63 & 0.64 & 0.08 \\
\hline $16: 2$ & 0.61 & 0.81 & 0.20 & 0.09 \\
\hline $16: 3$ & 0.79 & 0.71 & 0.08 & 0.49 \\
\hline 18:0 & 18.1 & 16.6 & 2.20 & 0.64 \\
\hline 18:1n-9 & 41.4 & 39.7 & 2.35 & 0.64 \\
\hline $18: 1 \mathrm{n}-7$ & 0.29 & 0.76 & 0.32 & 0.31 \\
\hline $18: 2 n-6$ & 1.56 & 2.24 & 0.20 & 0.03 \\
\hline $18: 3 n-3$ & 0.22 & 0.45 & 0.05 & 0.004 \\
\hline $18: 4 n-3$ & 0.23 & 0.20 & 0.04 & 0.61 \\
\hline $20: 3 n-6$ & 0.22 & 0.14 & 0.04 & 0.14 \\
\hline $20: 4 n-6$ & 0.16 & 0.06 & 0.03 & 0.03 \\
\hline $22: 5 n-3$ & 0.007 & 0.031 & 0.01 & 0.21 \\
\hline $24: 1 n-9$ & 0.01 & 0.05 & 0.04 & 0.54 \\
\hline SFA & 51.6 & 50.2 & 2.78 & 0.73 \\
\hline MUFA & 44.6 & 45.2 & 2.77 & 0.89 \\
\hline PUFA & 2.39 & 3.11 & 0.27 & 0.08 \\
\hline n-3 & 0.46 & 0.68 & 0.072 & 0.06 \\
\hline n-6 & 0.38 & 0.19 & 0.06 & 0.04 \\
\hline n- $6 / n-3$ & 1.02 & 0.32 & 0.16 & 0.01 \\
\hline
\end{tabular}

${ }^{1} \mathrm{SFA}=$ sum of saturated $\mathrm{FA} ; \mathrm{MUFA}=$ sum of monounsaturated FA; PUFA $=$ sum of polyunsaturated FA; $-3=$ sum of $n-3 F A$; and $n-6$ $=$ sum of n- 6 FA.

${ }^{2}$ Treatments were as follows: control $=$ dry cows at $256 \mathrm{~d}$ of pregnancy fed a dry-cow diet and postpartum lactating cow diet consisting of $5.8 \%$ ether extracts; $\mathrm{EF}=$ supplemented prepartum at $1 \mathrm{~kg} / \mathrm{d}$ per cow (7.9\% of DM) with extruded flaxseed, and postpartum until 100 DIM with a diet containing $9.2 \%$ of the same supplement. 


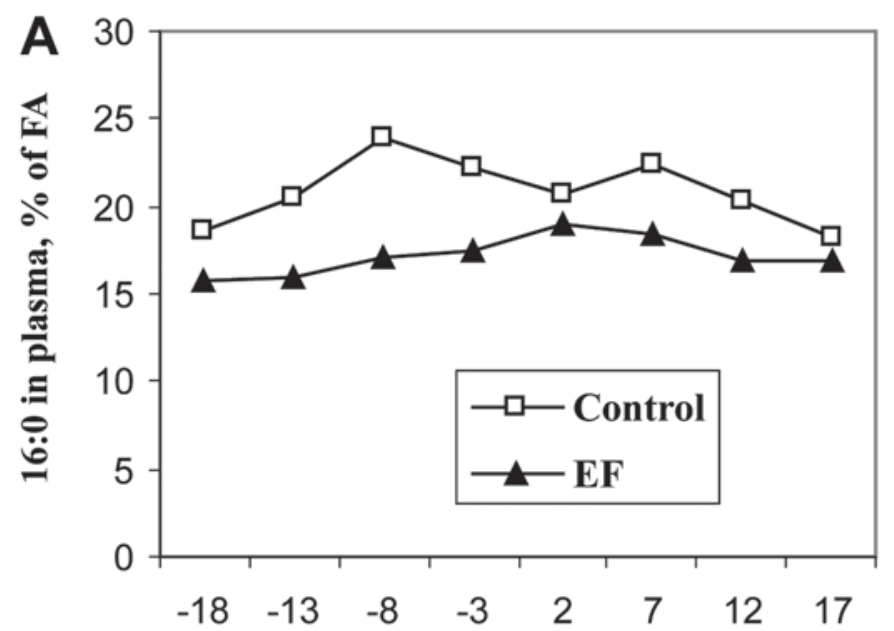

Days relative to parturition

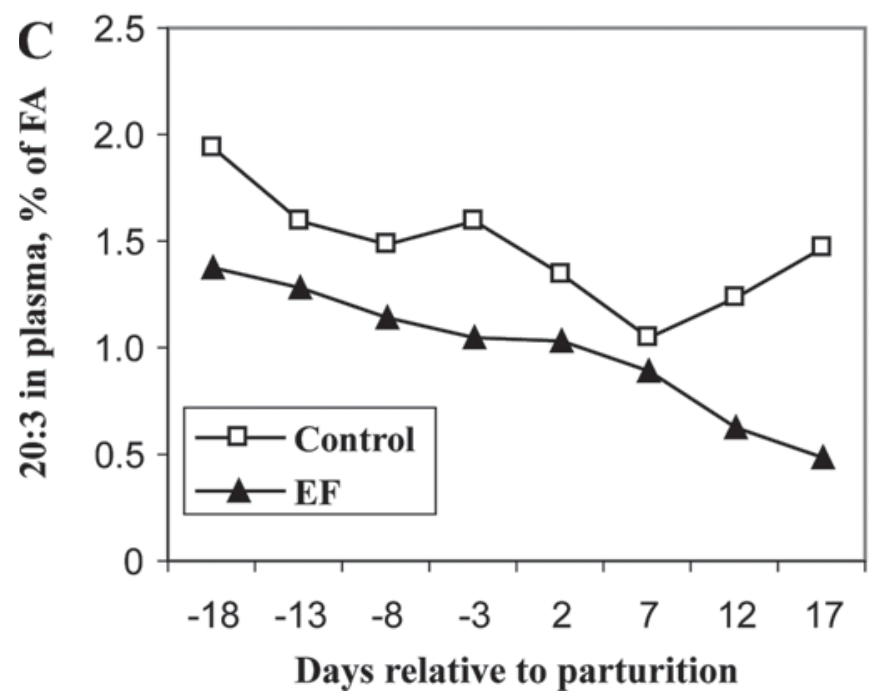

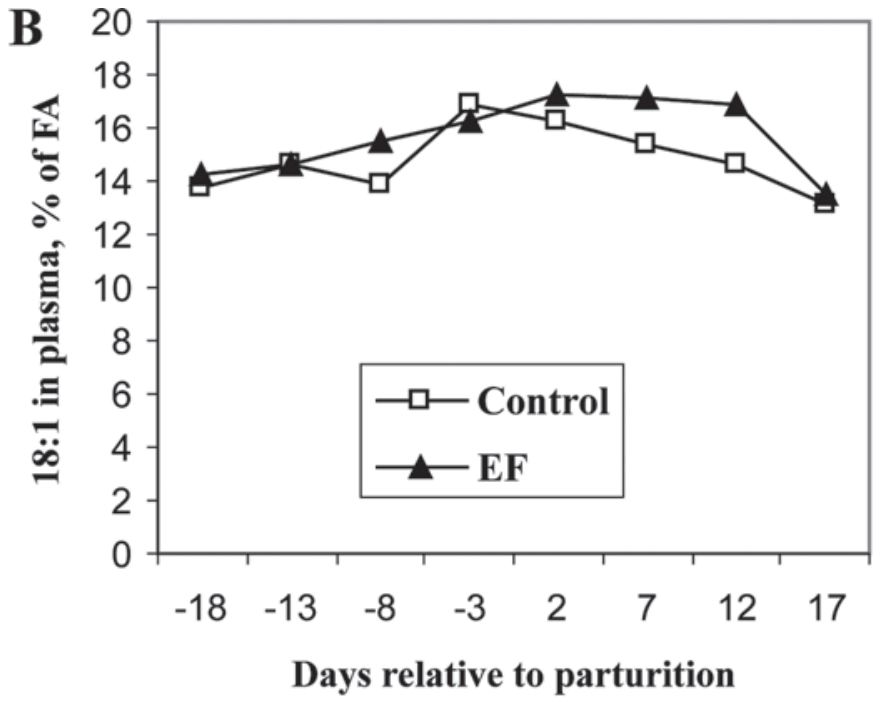

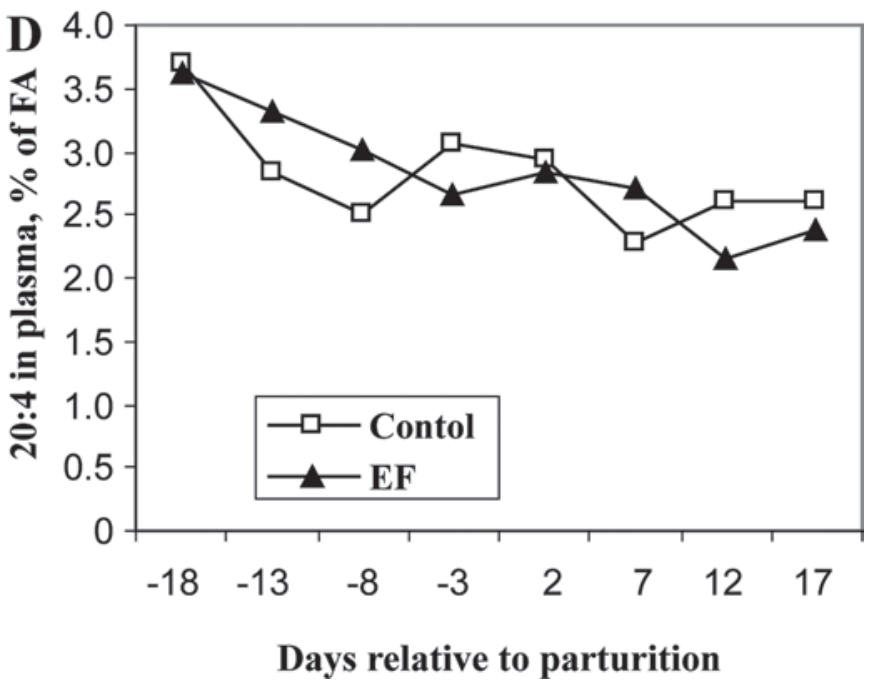

Figure 2. Temporal changes in plasma concentration (\% of total fatty acids) of (A) C16:0, (B) C18:1, (C) C20:3n-6, and (D) C20:4n-6 from $21 \mathrm{~d}$ precalving to $21 \mathrm{~d}$ postcalving in control $(\square)$ dry cows from $256 \mathrm{~d}$ of pregnancy fed a dry-cow diet and postpartum a lactating-cow diet containing 5.8\% ether extracts and extruded flaxseed (EF, $\mathbf{\Delta}$ ) cows prepartum supplemented with extruded flaxseed at $1 \mathrm{~kg} / \mathrm{cow}$ per day $(7.9 \%$ of DM) and postpartum through 100 DIM a diet containing 9.2\% of the same supplement. SEM for C16:0 = 1.05; C18:1 = 0.5; C20:3n-6 = $0.30 ; \mathrm{C} 20: 4 \mathrm{n}-6=0.37$.

Milk fat synthesis might be depressed by unique FA isomers generated in the rumen during biohydrogenation of unsaturated FA (Bauman and Griinari, 2003). Indeed, several studies reported higher concentrations of conjugated linoleic acid and C18:1 trans isomers in milk fat from cows supplemented with extruded flaxseed (Mustafa et al., 2003; Gonthier et al., 2005; Chilliard et al., 2009). However, the typical decrease in de novo synthesis of $<16$-carbon FA in response to MFD diets was not found in the present study (389.8 and $421.5 \mathrm{~g} / \mathrm{d}$ for EF and control, respectively; $P<$
0.38), in contrast with other reports (Mustafa et al., 2003; Akraim et al., 2007; Chilliard et al., 2009). On the other hand, rumen biohydrogenation rate increases with increasing unsaturation FA availability (Lock and Bauman, 2004), and we would expect the formation of unique MFD isomers in the rumen to increase and consequently lower milk fat formation as consumption of C18:3n-3 increases. However, in the present study, no significant correlation was found between fat content in milk and dietary C18:3n-3 consumption $(P<$ $0.25)$. It appears that the transfer of dietary C18:3n-3 
Table 6. Mean treatment effects on fatty acid (FA) composition $(\mathrm{g} / 100 \mathrm{~g}$ of FA) in milk fat

\begin{tabular}{|c|c|c|c|c|}
\hline \multirow[b]{2}{*}{ Item $^{1}$} & \multicolumn{2}{|c|}{ Treatment $^{2}$} & \multirow[b]{2}{*}{ SEM } & \multirow[b]{2}{*}{$P<$} \\
\hline & Control & $\mathrm{EF}$ & & \\
\hline $4: 0$ & 2.87 & 2.90 & 0.16 & 0.88 \\
\hline $6: 0$ & 1.91 & 1.91 & 0.08 & 0.96 \\
\hline $8: 0$ & 1.20 & 1.20 & 0.06 & 0.97 \\
\hline 10:0 & 2.78 & 2.78 & 0.20 & 0.99 \\
\hline $12: 0$ & 3.16 & 3.12 & 0.23 & 0.89 \\
\hline $14: 0$ & 10.31 & 10.22 & 0.47 & 0.88 \\
\hline $14: 1$ & 0.77 & 0.88 & 0.08 & 0.54 \\
\hline $15: 0$ & 0.79 & 0.82 & 0.03 & 0.58 \\
\hline $16: 0$ & 32.63 & 22.14 & 0.4 & 0.001 \\
\hline $16: 1$ & 1.30 & 1.34 & 0.1 & 0.75 \\
\hline $17: 0$ & 0.44 & 0.50 & 0.008 & 0.00 \\
\hline $17: 1$ & 0.14 & 0.17 & 0.02 & 0.22 \\
\hline 18:0 & 12.8 & 16.5 & 0.6 & 0.002 \\
\hline $18: 1 n-9$ & 23.6 & 28.2 & 0.8 & 0.002 \\
\hline $18: 2 \mathrm{n}-6$ & 3.28 & 3.43 & 0.11 & 0.36 \\
\hline Trans 18:3 & 0.29 & 0.20 & 0.06 & 0.06 \\
\hline $18: 3 n-3$ & 0.29 & 1.47 & 0.08 & 0.001 \\
\hline $18: 4 n-3$ & 0.09 & 0.10 & 0.01 & 0.64 \\
\hline 19:0 & 0.06 & 0.25 & 0.04 & 0.007 \\
\hline $19: 1$ & 0.05 & 0.08 & 0.04 & 0.64 \\
\hline $20: 0$ & 0.17 & 0.20 & 0.01 & 0.06 \\
\hline $20: 1 n-9$ & 0.24 & 0.84 & 0.08 & 0.001 \\
\hline $20: 2 n-6$ & 0.13 & 0.17 & 0.03 & 0.47 \\
\hline $20: 3 n-6$ & 0.16 & 0.17 & 0.03 & 0.82 \\
\hline $20: 4 n-6$ & 0.17 & 0.09 & 0.02 & 0.02 \\
\hline $20: 5 n-3$ & 0.06 & 0.10 & 0.02 & 0.26 \\
\hline $22: 0$ & 0.16 & 0.16 & 0.03 & 0.87 \\
\hline $22: 4 n-6$ & 0.03 & 0.08 & 0.01 & 0.03 \\
\hline $22: 5 n-3$ & 0.03 & 0.09 & 0.01 & 0.008 \\
\hline$\leq 15$ carbon & 22.91 & 23.0 & 1.0 & 0.96 \\
\hline SFA & 69.43 & 62.62 & 0.9 & 0.001 \\
\hline MUFA & 26.12 & 31.44 & 0.9 & 0.002 \\
\hline PUFA & 4.47 & 5.95 & 0.26 & 0.002 \\
\hline n-3 & 0.48 & 1.77 & 0.09 & 0.001 \\
\hline n-6 & 3.78 & 3.95 & 0.13 & 0.40 \\
\hline n- $6 / n-3$ & 8.29 & 2.28 & 0.45 & 0.001 \\
\hline
\end{tabular}

${ }^{1} \mathrm{SFA}=$ sum of saturated FA; MUFA = sum of monounsaturated FA; PUFA $=$ sum of polyunsaturated FA; $\mathrm{n}-3=$ sum of $\mathrm{n}-3 \mathrm{FA}$; and $\mathrm{n}-6$ $=$ sum of $n-6$ FA.

${ }^{2}$ Treatments were as follows: control $=$ dry cows at $256 \mathrm{~d}$ of pregnancy fed a dry-cow diet and postpartum lactating cow diet consisting of $5.8 \%$ ether extracts; $\mathrm{EF}=$ supplemented prepartum at $1 \mathrm{~kg} / \mathrm{d}$ per cow (7.9\% of DM) with extruded flaxseed, and postpartum until 100 DIM with a diet containing $9.2 \%$ of the same supplement.

into milk fat was more efficient in cows with a lower milk fat percentage, rather than in cows consuming large amounts of C18:3n-3 and, presumably, producing MFD intermediates in the rumen. Collectively, it might be concluded that an unknown mechanism limits the transfer rate of dietary $\mathrm{C} 18: 3 \mathrm{n}-3$ into milk-fat and that this process is more efficient in cows with low milk fat content, perhaps independent of MFD intermediates generated in the rumen.

De novo synthesis of short- and medium-chain FA was not affected by treatment; however, in the present study, C16:0, which is partly derived from de novo synthesis (Baumgard et al., 2001), was appreciably re-
Table 7. Mean treatment effects on fatty acid (FA) yields $(\mathrm{g} / \mathrm{d})$ in milk fat

\begin{tabular}{|c|c|c|c|c|}
\hline \multirow[b]{2}{*}{ Item $^{1}$} & \multicolumn{2}{|c|}{ Treatment $^{2}$} & \multirow[b]{2}{*}{ SEM } & \multirow[b]{2}{*}{$P<$} \\
\hline & Control & $\mathrm{EF}$ & & \\
\hline 4:0 & 50.4 & 49.1 & 3.4 & 0.79 \\
\hline 6:0 & 33.6 & 32.2 & 2.0 & 0.61 \\
\hline $8: 0$ & 21.0 & 20.3 & 1.5 & 0.72 \\
\hline 10:0 & 48.7 & 46.7 & 4.3 & 0.75 \\
\hline $12: 0$ & 55.3 & 52.2 & 5.0 & 0.66 \\
\hline 14:0 & 180.9 & 170.3 & 11.0 & 0.51 \\
\hline $14: 1$ & 13.6 & 14.0 & 1.5 & 0.83 \\
\hline $15: 0$ & 13.9 & 13.7 & 0.6 & 0.80 \\
\hline 16:0 & 573.8 & 370.6 & 23.0 & 0.001 \\
\hline $16: 1$ & 23.0 & 22.8 & 2.2 & 0.94 \\
\hline $17: 0$ & 7.9 & 8.4 & 0.4 & 0.33 \\
\hline $17: 1$ & 2.5 & 2.9 & 0.35 & 0.38 \\
\hline 18:0 & 225.0 & 277.0 & 20.0 & 0.08 \\
\hline $18: 1 n-9$ & 417.0 & 472.6 & 25.8 & 0.15 \\
\hline $18: 2 \mathrm{n}-6$ & 57.9 & 56.8 & 2.0 & 0.72 \\
\hline Trans 18:3 & 3.5 & 3.1 & 1.0 & 0.75 \\
\hline $18: 3 n-3$ & 5.2 & 24.1 & 0.6 & 0.001 \\
\hline $18: 4 n-3$ & 1.6 & 1.7 & 0.2 & 0.69 \\
\hline 19:0 & 0.9 & 4.1 & 0.6 & 0.004 \\
\hline $19: 1$ & 0.9 & 1.3 & 0.7 & 0.72 \\
\hline $20: 0$ & 3.0 & 3.4 & 0.23 & 0.23 \\
\hline 20:1n-9 & 4.3 & 14.1 & 1.6 & 0.001 \\
\hline $20: 2 \mathrm{n}-6$ & 2.3 & 2.9 & 0.6 & 0.51 \\
\hline $20: 3 n-6$ & 2.8 & 3.0 & 0.6 & 0.85 \\
\hline $20: 4 n-6$ & 3.0 & 1.5 & 0.4 & 0.02 \\
\hline $20: 5 n-3$ & 1.1 & 1.6 & 0.4 & 0.32 \\
\hline $22: 0$ & 2.8 & 2.7 & 0.4 & 0.87 \\
\hline $22: 4 n-6$ & 0.6 & 1.4 & 0.2 & 0.02 \\
\hline $22: 5 n-3$ & 0.5 & 1.6 & 0.3 & 0.01 \\
\hline$\leq 15$ carbon & 421.5 & 389.8 & 23.0 & 0.38 \\
\hline$\overline{\mathrm{S} F A}$ & $1,219.1$ & $1,051.4$ & 57.0 & 0.06 \\
\hline MUFA & 460.9 & 527.6 & 29.0 & 0.13 \\
\hline PUFA & 78.1 & 98.0 & 3.7 & 0.003 \\
\hline n-3 FA & 8.3 & 29.1 & 1.0 & 0.001 \\
\hline n-6 & 66.5 & 65.7 & 2.7 & 0.84 \\
\hline n- $6 / n-3$ & 146.4 & 38.6 & 9.1 & 0.001 \\
\hline
\end{tabular}

${ }^{1} \mathrm{SFA}=$ sum of saturated $\mathrm{FA} ; \mathrm{MUFA}=$ sum of monounsaturated FA; PUFA $=$ sum of polyunsaturated FA; $n-3=$ sum of $n-3$ FA; and n- 6 $=$ sum of n-6 FA.

${ }^{2}$ Treatments were as follows: control $=$ dry cows at $256 \mathrm{~d}$ of pregnancy fed a dry-cow diet and postpartum lactating cow diet consisting of $5.8 \%$ ether extracts; $\mathrm{EF}=$ supplemented prepartum at $1 \mathrm{~kg} / \mathrm{d}$ per cow (7.9\% of DM) with extruded flaxseed, and postpartum until 100 DIM with a diet containing $9.2 \%$ of the same supplement.

duced in the EF cows. It might be that C16:0 synthesis was decreased partly by MFD intermediates, but also as a result of markedly less C16:0 consumption by EF versus control cows (187.7 and $559.8 \mathrm{~g} / \mathrm{d}$ per cow, respectively), in which EF cows could not compensate for the vast gap between groups in availability of dietary C16:0, and thereby total milk fat was depressed in the EF group. It has been shown that about $60 \%$ of $16: 0$ present in abomasally infused butterfat is transferred into milk (Kadegowda et al., 2008), and C16:0 has also been demonstrated as the most preferred substrate for the initial step of triacylglycerol synthesis in bovine mammary microsomes (Kinsella and Gross, 1973). These 

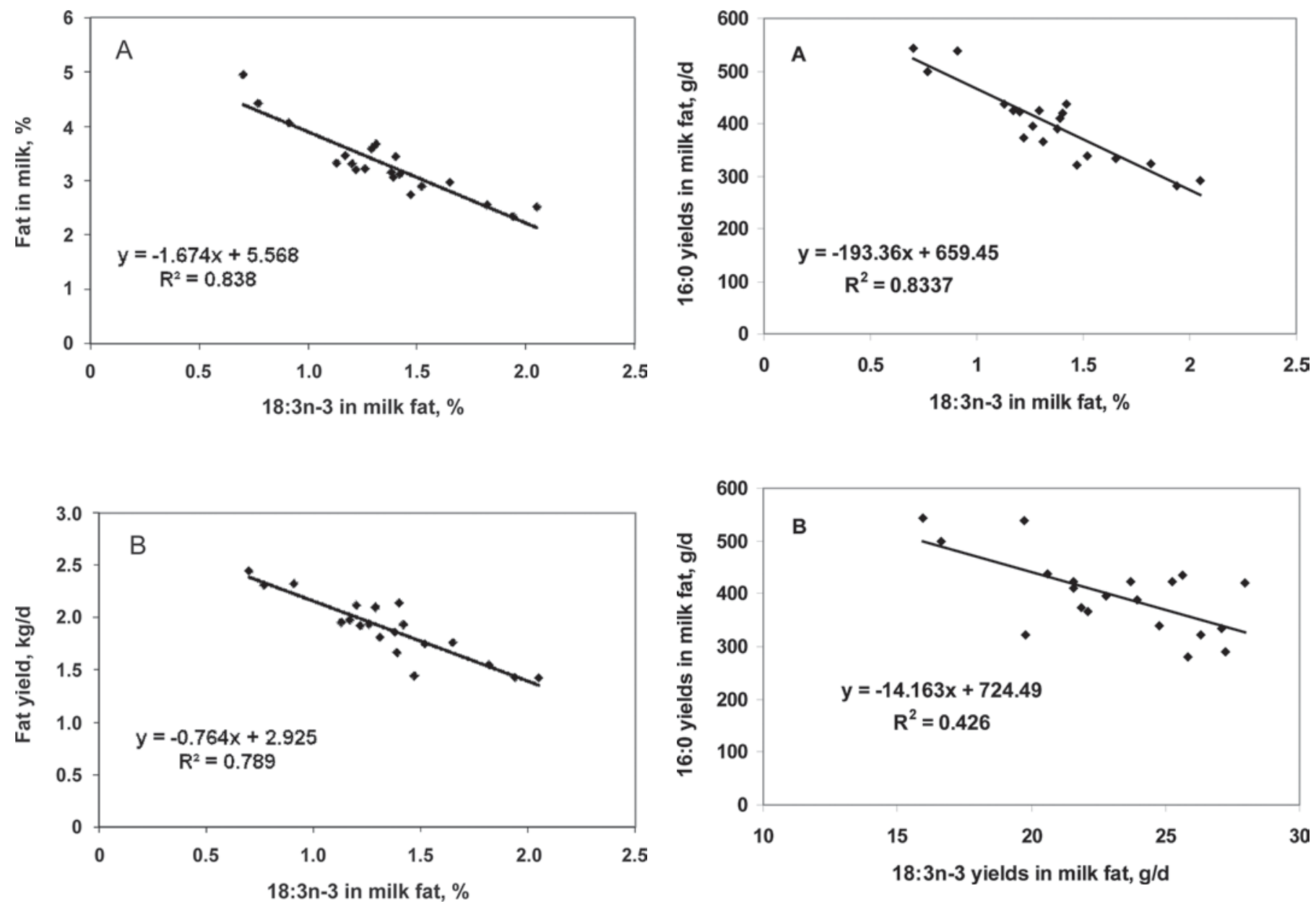

Figure 3. Relationships between milk fat content of C18:3n-3 and (A) fat percentage in milk and (B) daily milk-fat yields in cows supplemented prepartum with extruded flaxseed $(\mathrm{EF})$ at $1 \mathrm{~kg} / \mathrm{cow}$ per day (7.9\% of DM) and postpartum through 100 DIM with a diet containing $9.2 \%$ of the same supplement.

findings emphasize the central role of C16:0 in milk fat synthesis and might explain the lower fat percentage found in the EF cows as a result of lower palmitic acid consumption compared with control cows.

Moreover, C16:0 yields in EF cows were negatively correlated with 18:3n-3 content $(\mathrm{r}=-0.91 ; P<0.0001$; Figure 4A) and yield $(\mathrm{r}=-0.65 ; P<0.002$; Figure 4B) in milk fat. Because no decrease in de novo synthesis of $<16$-carbon FA was observed, it could also be speculated that C18:3n-3 depresses de novo synthesis of C16:0, but not of shorter chain $(<16)$ FA, which thereby reduces overall milk fat content and yield. However, further research is needed to elucidate this hypothesis.

\section{CONCLUSIONS}

Feeding transition cows an increased amount of extruded flaxseed that contained a high proportion of

Figure 4. Relationships between yield of C16:0 and (A) percentage of C18:3n-3 in milk fat and (B) yields of C16:0 and C18:3n-3 in milk fat in cows supplemented prepartum with extruded flaxseed (EF) at 1 $\mathrm{kg} / \mathrm{cow}$ per day (7.9\% of DM) and postpartum through 100 DIM with a diet containing $9.2 \%$ of the same supplement.

C18:3n-3, from 3 wk before calving until 100 DIM, enhanced DMI and milk yield, decreased milk fat content, and improved EB. Although relatively large amounts of $\mathrm{C} 18: 3 \mathrm{n}-3$ were offered to and consumed by cows, the enrichment of milk fat with n-3 FA was limited to approximately $2 \%$ and was negatively correlated with milk fat content. No decrease in de novo synthesis of $<16$-carbon FA was found, whereas C16:0 was markedly decreased in the EF cows. Therefore, although we did not determine MFD intermediates in milk fat, it appears that the increase in C18:3n-3 content in milk fat was more efficient in cows with low milk fat percentages, independent of any in-rumen generation of MFD isomers. Moreover, C16:0 consumption was markedly lower in the EF than in the control cows. The EF cows could not compensate for the vast gap between groups in dietary C16:0 availability, resulting in depressed total milk fat in this group. Alternatively, it might also 
be hypothesized that C18:3n-3 itself depresses de novo synthesis of C16:0, but not that of shorter chain FA, and thereby reduces overall milk fat content and yield.

\section{ACKNOWLEDGMENTS}

The authors are grateful to Pierre Weill and Valorex (Combourtillé, France) for the kind donation of the extruded flaxseed supplement (Valomega-160). We also thank the entire staff of the experimental dairy farm at the Volcani Center (Bet Dagan, Israel) for their assistance with animal care.

\section{REFERENCES}

Akraim, F., M. C. Nicot, P. Juaneda, and F. Enjalbert. 2007. Conjugated linolenic acid (CLnA), conjugated linoleic acid (CLA) and other biohydrogenation intermediates in plasma and milk fat of cows fed raw or extruded linseed. Animal 1:835-843.

Ambrose, D. J., J. P. Kastelic, R. Corbett, P. A. Pitney, H. V. Petit, J. A. Small, and P. Zalkovic. 2006. Lower pregnancy losses in lactating dairy cows fed a diet enriched in $\alpha$-linolenic acid. J. Dairy Sci. 89:3066-3074.

AOAC. 1990. Official Methods of Analysis. 14th ed. Association of Official Analytical Chemists, Arlington, VA.

Bauman, D. E., and J. M. Griinari. 2003. Nutritional regulation of milk fat synthesis. Annu. Rev. Nutr. 23:203-227.

Baumgard, L. H., J. K. Sangster, and D. E. Bauman. 2001. Milk fat synthesis in dairy cows is progressively reduced by increasing supplemental amounts of trans-10, cis-12 conjugated linoleic acid (CLA). J. Nutr. 131:1764-1769.

Bernal-Santos, G., J. W. Perfield, D. M. Barbano, D. E. Bauman, and T. R. Overton. 2003. Production responses of dairy cows to dietary supplementation with conjugated linoleic acid (CLA) during the transition period and early lactation. J. Dairy Sci. $86: 3218-3228$

Bilby, T. R., T. Jenkins, C. R. Staples, and W. W. Thatcher. 2006. Pregnancy, bovine somatotropin, and dietary n-3 fatty acids in lactating dairy cows: III. Fatty acid distribution. J. Dairy Sci. 89:3386-3399.

Bremmer, D. R., L. D. Ruppert, J. H. Clark, and J. K. Drackley. 1998. Effects of chain length and unsaturation of fatty acid mixtures infused into the abomasum of lactating dairy cows. J. Dairy Sci. 81:176-188.

Castañeda-Gutiérrez, E., T. R. Overton, W. R. Butler, and D. E. Bauman. 2005. Dietary supplements of two doses of calcium salts of conjugated linoleic acid during the transition period and early lactation. J. Dairy Sci. 88:1078-1089.

Chilliard, Y., C. Martin, J. Rouel, and M. Doreau. 2009. Milk fatty acids in dairy cows fed whole crude linseed, extruded linseed, or linseed oil, and their relationship with methane output. J. Dairy Sci. 92:5199-5211.

Drackley, J. K., T. H. Klusmeyer, A. M. Trusk, and J. K. Clark. 1992. Infusion of long-chain fatty acids varying in saturation and chain length into the abomasum of lactating dairy cows. J. Dairy Sci. $75: 1517-1526$.

Edmonson, A. J., I. J. Lean, L. D. Weaver, T. Farver, and G. Webster. 1989. A body condition scoring chart for Holstein dairy cows. J. Dairy Sci. 72:68-78.
Glasser, F., M. Doreau, A. Ferlay, and Y. Chilliard. 2007. Technical note: Estimation of milk fatty acid yield from milk fat data. J. Dairy Sci. 90:2302-2304.

Gonthier, C., A. F. Mustafa, D. R. Ouellet, P. Y. Chouinard, R. Berthiaume, and H. V. Petit. 2005. Feeding micronized and extruded flaxseed to dairy cows: Effects on blood parameters and milk fatty acid composition. J. Dairy Sci. 88:748-756

Harvatine, K. J., and M. S. Allen. 2006. Effects of fatty acid supplements on milk yield and energy balance of lactating dairy cows. J. Dairy Sci. 89:1081-1091.

International Dairy Federation. 2000. IDF standard 141c:2000: Determination of milk fat, protein and lactose content guidance on the operation of mid-infrared instruments. International Dairy Federation, Brussels, Belgium.

Kadegowda, A. K. G., L. S. Piperova, P. Delmonte, and R. A. Erdman. 2008. Abomasal infusion of butterfat increases milk fat in lactating dairy cows. J. Dairy Sci. 91:2370-2379.

Khas-Erdene, Q., J. Q. Wang, D. P. Bu, L. Wang, J. K. Drackley, Q. S. Liu, G. Yang, H. Y. Wei, and L. Y. Zhou. 2010. Short communication: Responses to increasing amounts of free $\alpha$-linolenic acid infused into the duodenum of lactating dairy cows. J. Dairy Sci. 93:1677-1684.

Kinsella, J. E., and M. Gross. 1973. Palmitic acid and initiation of mammary glyceride synthesis via phosphatidic acid. Biochim. Biophys. Acta 316:109-113.

Lock, A. L., and D. E. Bauman. 2004. Modifying milk fat composition of dairy cows to enhance fatty acids beneficial to human health. Lipids 39:1197-1206.

Moallem, U., Y. Folman, A. Bor, A. Arav, and D. Sklan. 1999. Effect of calcium soaps of fatty acids and administration of somatotropin on milk production, preovulatory follicular development, and plasma and follicular fluid lipid composition in high yielding dairy cows. J. Dairy Sci. 82:2358-2368.

Moallem, U., M. Katz, A. Arieli, and H. Lehrer. 2007. Effects of peripartum propylene glycol or fats differing in fatty acid profiles on feed intake, production, and plasma metabolites in dairy cows. J. Dairy Sci. 90:3846-3856.

Mustafa, A. F., P. Y. Chouinard, and D. A. Christensen. 2003. Effects of feeding micronised flaxseed on yield and composition of milk from Holstein cows. J. Sci. Food Agric. 83:920-926.

NRC. 2001. Nutrient Requirements of Dairy Cattle. 7th rev. ed. National Academy Press, Washington, DC.

Odens, L. J., R. Burgos, M. Innocenti, M. J. VanBaale, and L. H. Baumgard. 2007. Effects of varying doses of supplemental conjugated linoleic acid on production and energetic variables during the transition period. J. Dairy Sci. 90:293-305.

Petit, H. V., C. Germiquet, and D. Lebel. 2004. Effect of feeding whole, unprocessed sunflower seeds and flaxseed on milk production, milk composition, and prostaglandin secretion in dairy cows. J. Dairy Sci. 87:3889-3898.

Petit, H. V., M. F. Palin, and L. Doepel. 2007. Hepatic lipid metabolism in transition dairy cows fed flaxseed. J. Dairy Sci. 90:47804792 .

Rukkwamsuk, T., M. J. H. Geelen, T. A. M. Kruip, and T. Wensing. 2000. Interrelation of fatty acid composition in adipose tissue, serum, and liver of dairy cows during the development of fatty liver postpartum. J. Dairy Sci. 83:52-59.

SAS Institute. 2002. User's Guide: Statistics. Version 9.2. SAS Inst., Cary, NC.

Simopoulos, A. P. 2002. Omega-3 fatty acids in inflammation and autoimmune diseases. J. Am. Coll. Nutr. 21:495-505.

Wathes, D. C., D. R. E. Abayasekara, and R. J. Aitken. 2007. Polyunsaturated fatty acids in male and female reproduction. Biol. Reprod. 77:190-201. 